\title{
ANALYZING THE DETERMINANTS OF EMPLOYEE RETENTION: A CASE OF PHARMACEUTICAL COMPANIES IN PAKISTAN \\ Anum Asif ${ }^{1}$ and Nayab Gul ${ }^{2}$
}

\begin{abstract}
Employee retention could be a crucial issue within the pharmaceutical industry of Pakistan. As of now workplace and workers both are influenced at the same time with this genuine issue. Therefore there is a need of research to retain the assets of the company. The main cause of the following research is to demonstrate the factors which influence the employee retention. The variables we are using are job satisfaction, salary \& rewards, career development \& superior support. Sample size of the study was 250 out of 250 questionnaires was filled by 214 employees in which $89.0 \%$ were male and $11.0 \%$ were females of different pharmaceutical firms of Pakistan. In this we use quantitative research the study is based on mono method research. The collected primary data has been analysed through SPSS \& Smart PLS and correlational analysis. If the result of the study is been concluded so it has been shown that all the variables have significant relationship and alternative hypothesis are accepted.

As a result the uniqueness of the research study is also significant which shows that working on their talented people (employees) and to keep them satisfying is important for the productivity of organization. The study has different indication as it has given new ways to the pharmaceutical sector to retain their employees and reduce the cost of hiring by retention.
\end{abstract}

Key terms: Employees Retention, Supervisor Support, Job Satisfaction, Career Development and Salary and Rewards.

\section{INTRODUCTION}

\section{Background}

Pharmaceutical companies are commercial businesses which are licensed to research, find, make the drugs for healthcare and then they distribute in the market. They have certain rights and legal obligations of work for healthcare. Pharmaceutical industry formally initiated in the

1. Benazir School of Business, BBSUL 
$18^{\text {th }}$ century and now they are one of the profitable industries in the world, contributing a high share of GDP to market economies as well as supplying the healthcare products for human life survival.

In the past years as well as in our current era, we have examined a lot of reasons as to why the employees leave the organization. A lot of data is available which reflects on the reasons for retention of employees. As we are entering into the advanced era retention has always been a key factor, which is rapidly growing and becoming more challenging for the organizations in order to facilitate and retain their employees. Employee retention is one of the crucial problem or challenging factors for the workplaces. (Schechter, Shaked, \& H., 2018) As one employee left the organization so it has huge loss incur of both skills and recruiting cost of new hire. So, organizations need to know that that from which factors they can save their talented people and their skills, their money and most important their time.

The thought of employee retention created after the industrial revolution during the early $19^{\text {th }}$ century and gained consistency and popularity in 1970's and mid 1980's. The idea behind this development based on the theoretical grounds that many individuals joined various organizations and remained with the organizations for a very long time (Sinha \& Sinha, 2012). It has been observed in one of the study that employee does not retain in an organization for a single factor there are multiple factor behind retention. ( Kossiv, Xu, \& Kalgora, 2016)

According to study of (Singh, 2018) factors that mostly effect the rate of employee retention are included compensation, work life balance, self-grooming, great interchange. The study also emphasized on management style to increase employee retention.

Employee retention is considered as the ability of an organization to reduce their turnover rate. It is an important factor for an organization because to hire a new employee is not simple as many costs are hidden behind the process. (Afshan, Qamar, \& Afzal, 2018) Study states that 
there is a need to focus on those factors which lead the organization towards success and long term achievements and also affecting the employees to stay and work for an organization for long term. Another study shows that there must be retention strategies to convey the satisfaction needs of employees and provide strategic bases for organizations to work effectively (Kroeger, 2010).

In pharmaceutical industries it is observed that there is lack of employee retention approach and strategies. Indeed. Only high rewards and perks are not enough to retain the employees. Losing a senior employee impacts negatively on organizations because with loss of an experienced employee, organizations have to hire new employee as replacement and provide training to the new incumbent. There is a research on pharmaceutical firm on Peshawar Pakistan that why medical representative switch their job or organization and the clear factor our sale increasing, career development, supervisor support, management relationship, employees retention, employees compensation these factors have a strong positive significance influence on pharmaceutical employees of Peshawar Pakistan. Moreover, this research found the factor that "Salary" is the important factor for pharmaceutical employees as compared to other variable and other variable comes out at next key of turnover causes. These factors impact the turnover at pharmaceutical employees. ( Hejase, Dirani, Hamdar, \& Hazimeh, 2016)

\section{Industry Brief}

The pharmaceutical industry is one of the drug manufacturing industries of Pakistan. Nowadays Pakistan has around 400 pharmaceutical companies which can meet around $80 \%$ of the country's request of wrapped up pharmaceutical products. The pharmaceutical industry in Pakistan has experienced an essential development of $17 \%$ amid 2013, which is more than the worldwide pharmaceutical normal yearly development rate of 8 per cent (Baig, Saqib, Abrar, \& Bashir, 2011). Moreover, the pharmaceutical companies in Pakistan sent out sum to US $\$ 200$ 
million yearly in 18 diverse nations with a trade vision of US\$500 million in 2013 (Imam \& Ali, 2018).

According to the report of Pakistan's Pharmaceutical Manufacturers' Association (PPMA) July 2017 people switched job because of high salary and their career advancement people left job because they get an offered a new chance to grow from other organization. Even good employees are quite too when they didn't get learning and development opportunities from organization. Mostly people switched their job to move towards a better opportunity and higher attractive salary. Employees easily quite from organization but retaining is the only main factor which is which is help you out to stay your employees for the long at organization and reduce your cost for new hiring and training. Retaining the employees reducing the turnover rate too which are beneficial for organization.

Some of the major pharmaceutical companies currently actively working in Pakistan are GlaxoSmithKline; Getz Pharma (Private) Limited; Abbott Laboratories Pakistan Limited; Sami Pharmaceutical (Private) Limited; the Searle Company Limited; Hilton Pharma (Private) Limited; Ferozesons Laboratories; Pfizer Pakistan Limited; Bayer; Wyeth Pakistan Limited and others.

\section{Research Problem}

Every organization has a goal to retain their employees. Holding talented people is an advantage for a firm since the information and abilities of the employees are critical for organizations in determining their competitive advantage. Employee retention may be a one of the foremost and fundamental issues examined by organizational pioneers since of the lack of talented workforce, money related improvement and huge laborer turnover (Imam \& Ali, 2018). It is fundamental for organizations through the commerce strategy, to bring and retain 
quality labors in the organization. Due to high turnover rate, new employees hiring, and the cost increase related to this process demonstrate that it is better to retain the employees instead of their turnover.

Employee retention is to one of the enormous problem in organization in present days. Great and talented workers ought to be held by organizations. Numerous organizations do not respect their workers due to which worker switch their jobs to seek for better working environments and leave disgraceful workplaces as soon as they discover any good alternative opportunity. Thus this study intends for find the reasons of employee turnover, and investigate the factors which help employee retention in organizations.

\section{Research Question}

1. Does the supervisor support and employee retention has a positive relation?

2. Does the job satisfaction and employee retention have a positive relation?

3. Do the salary \& rewards and employee retention has a positive relation?

4. Do the career development opportunities and employee retention has a positive relation?

\section{Objectives of the Study}

To determine the factors which significantly influence employees to retain or leave the organization. For this study we will first examine the factors that are affecting employee retention through available literature and then we will investigate the impact of those factors in effect to the pharmaceutical companies in Pakistan. 
- Effect on organization of retention polices.

- Finding the retention procedures for the organizations.

- Highlighting the reasons why individuals are resigning.

- Identifying the ways to reduce turnover.

\section{Justification}

In today's world competition in every field everywhere is common especially in organizations so to face the change and compete with the competitor's organizations must satisfy their employees and to make an organization alive in this competitive world employee retention is necessary. We have chosen this topic to highlight the factors behind the turnover and employee retention because employees are the beneficial for an organization, without them organization can't perform effectively.

\section{Limitations}

Certain limitation of this study is that data will be collected only from the employees of pharmaceutical companies in Pakistan to know the factors which relate to the turnover.

\section{LITERATURE REVIEW}

\section{Employee Retention}

Employee retention is the ability of an organization to retain its talented people for a long time period. It is necessary for an organization to retain the employees because there is too much cost regarding recruitment and organization lost their polished employees. Study of India (Sinha \& Shukla, 2013) was about study of employee retention in the pharmaceuticals Sector in Dehradun city in which they selected respondents randomly from pharmaceutical companies. They have used dichotomous questions 126 questionnaires were analyzed in which they have found that pharmaceutical industry have high retention rate than other industries. 
The main reason they had found by this study is $60 \%$ of employees have no issue with their jobs they have full job security they are satisfied with the working hours.

Organizations are centring on the issue of longer retention of their experienced, senior and useful employees. Organizations are worried to save a talented representative for a more extended time. There are numerous motivations to hold representatives, and its main role is to recruit and give preparing another labourer is a delayed and expensive cycle. This method causes the loss of important assets. To accomplish targets and objectives organizations are attempting to do at its best to continue existing. A study of Pakistan (Salman, Mehmood, Aftab, \& Mahmood, 2016) was about the impact of safety health environment on employee retention and pharmaceutical industry in which surveys conducted through questionnaire 250 respondents fill the questionnaire and data analysed through SPSS and Amos in which they shows that pharmaceutical industries attempt retention strategies to retain their talented people.

\section{Supervisor Support}

Supervisor support is a significant factor for employee retention in an organisation. A research of Malaysia (Bibi, ahmed, \& Majid, 2018) was conducted in which 250 faculty members was selected for survey. Above study explores the effect of training and development and supervisor support on employee retention. In this study superior support and employee retention has a positive significant relationship therefore the upper management needs to provide appropriate support to their employees.

However a study of London (Sucharski, Stinglhamber, \& Vandenberghe, 2002) also shows the positive significance relation of superior support and employee retention in which the study is about the exploration of the relationship among employee retention superior support and organisational support, there sample size was about 300 they collect data through questionnaire and collected in sealed envelopes. 
Additionally another study of (Irshad \& Afridi, 2007) hence proved that if employees are given importance will work efficiently in an organisation and increase the productivity so it is prove that superiors support has positive significance on employee retention. The study is about the relationship between employee retention and human resource management practices in an organisation. In this study (Irshad \& Afridi, 2007) worked on the past literatures the way in which people manage and improving at work.

Another study of Pakistan (Malik, Baig, \& Manzoor, 2020) about Impact of HR practices on retention rate: the role of supervisor support, which shows employee retention, has positive relation with supervisor support. The survey conducted through questionnaire and data analyzed through SPSS and they follow theory of Maslow hierarchy needs and show that if employee treated well or they have a good relation with their superiors so they work for the organization for the long time.

Study of Pakistan by (Anis A. , Kashif-ur-Rehman, Ijaz-Ur-Rehman, Khan, \& Humayoun, 2011) complete of 450 surveys was shipped off workers of six drug organizations. Out of the aggregate, 320 usable polls were incorporated for information investigation. They utilized essential date strategy this investigation clarify the connections of chief help on drug industry. Supervisor's help make the open door for the employee to interface and speak with partners to know them well for filling in as a solid collaboration. The coordination of superiors and employees in declining period gives benefit to the organization.

Admittedly the study of (Mishra \& Mishra, 2013) hence proved that through research it has been examined that $85 \%$ of all problems in an organisation support associate with superior support the major factor of employee retention in an organisation is superior support employees remain motivated if they are well treated and supported by organisations.

H1 = Supervisor support has a positive and significant effect on employee retention .

\section{Job Satisfaction}


Job satisfaction is also an important factor to reduce the turnover rate of an organisation. A study of Dhaka (Kabir \& Parvin, 2011) was about factors affecting employee job satisfaction of Pharmaceutical sector in this author shows the positive impact of job satisfaction on employee retention. Employees only satisfied through his jobs when organisation provides facilities to their employees.

Moreover the study of Pakistan that (Ashtraf \& Siddiqui, 2018) works on the impact of employee retention the role of psychological, capital, control at work, general wellbeing and job satisfaction. In these they conducted a survey of 200 employees of longitudinal companies in Pakistan by using 5 point Likert scale questionnaire.

Hence study of Pakistan (khan \& Aleem, 2014) demonstrates that job satisfaction in such case employee with the low level of dissatisfaction which turns into the rate of turn over and employment. A study further shows that ratio of turnover indicates a level of dissatisfaction of employee. The research conducted through questionnaire and sample size was 270 and respondents were 200 who filled their questionnaire.

Another case study of (Anis A. , Kashif-ur-Rehman, Ijaz-Ur-Rehman, Khan, \& Humayoun, 2011) was about the issue in pharmaceutical industry which is job satisfaction of the employees and their retention issue in which 450 questionnaires were distributed among six pharmaceutical companies. Out of the 450 , the study gets 320 usable questionnaires for data analysis. For model testing Structural Equation Modelling (SEM) was used. The results conclude the positive and significance. This study show the relationship of job satisfaction which impact on employee retention and it's indicated the positive relationship that the more employee are satisfied with their job and organization they are more willing to work in an organization and satisfied employees are more loyal and unlikely to switch their job and it's helped to increase the productivity. 
It has been concluded that job satisfaction has positive relation with employee retention consequently a study of Pakistan (Salman, Mehmood, Aftab, \& Mahmood, 2016) was about the impact of safety health environment on employee retention and pharmaceutical industry in which surveys conducted through questionnaire 250 respondents fill the questionnaire and data analysed through SPSS and Amos.

H2 = Job satisfaction has a positive and significant effect on employee retention.

\section{Salary \& Rewards}

Employee only motivated by the rewards he/she get from the organization. The research (Kabir \& Parvin, 2011) indicates that employees are working for money they are attracted by the handsome pay. If organizations increase the salary and benefits of employees so it increase their service quality and showing their behaviour towards positivity and they want to stay long with organization.

Another study of (Ruvimbo \& Ngirande, 2014) used quantitative research in which 180 nurses selected randomly as respondents it was about the relationship of retention and incentives and their effect. The study determines the impact of employee rewards and perks leads to employee retain for long time period. The study clearly shows the optimistic relationship between rewards and job retention. It indicates that the more you provide benefits to your employee they highly interact with organization and stay longer with the same industry because they get satisfied perks and benefits.

Likewise another study (Akhter \& Iqbal, 2017) is about Effects of Job Organizational Culture, Benefits, and Salary on Job Satisfaction ultimately affecting employee retention. They conduct survey through questionnaires using primary research to conduct the research. Salary and rewards are the very significant factor for every employee they desire to get internal and external reward on their special contributions and performances made by them for organization 
objectives. Salary and other benefits/packages is strong tool for company to retain their employees.

Moreover the study (Irshad \& Afridi, 2007) is based on research reviews relevant literature to indicate that which factor are helpful to retained employees. Salary and Rewards are the key factor of any organization which motivates the employees and motivation leads to employees' retention in the organization. Rewards and promotions should be on merit basis which help in production and retention.

To sum up it is proved by the study (Chiu \& Li-Ping Tang, 2002) that salary and rewards has positive impact on employee retention. This research paper conducted two studies in which data collected from 2 different cities like in Hong Kong they got 583 respondents and from People's Republic of China (PRC) they got 121 respondents. They determine that salary and rewards are the strongest factor to retained employees because they worked for money it's valuable for them. Basic salary, rewards, year-end bonus, annual leave and mortgage loan were the important factor to retain the employees. These factors reflected to Hong Kong employees. H3 = Salary \& rewards has a positive and significant effect on employee retention.

\section{Career Development Opportunities}

Career development is the main factor for which employee retain in an organization. A study of Malaysia was conducted about the impact of career development activities practices on employee retention, the research conducted through questionnaire which was distributed among 30 employees and analyzed through SPSS. The study (Nagarathanam, Venkitasamy, \& Attiah, 2018) indicates the positive relation of career development and employee retention. 
According to this study career development opportunity is the only way to keep an employee in an organization for a long time period and move organization towards productivity.

Another study of (George, 2015), about the topic what factors induce employees to retain in organizations. It is a cross sectional study in which survey is conducted through questionnaire and 138 workers participated in the survey and analyzed through SPSS. The study shows that employees are capable to promotion and working efficiently in an organization. Employee focuses on work when he sees his personal benefits. It also shows that employee turnover rate may be the cause of low career development.

In contrast the study of (Chew \& C. A. Chan, 2008) is about the human resource practices and organizational commitment and intention to stay. The study indicates the negative impact of career development factor on employee retention. The study shows that career development has not significant relationship with employee retention. The study opposed too many other studies. The survey is conducted by taking interviews though Delphi technique. Interviews take from 13 experts, 12 HR Manager and 457 employees of Australia. Structural equation modeling was used to test data.

Report on examining the factors contributing to employee retention of BEXIMCO Pharmaceuticals - The case study on HR department of BEXIMCO Pharma by (Ashika, 2020) they take participates from the age group between 31-40 years old agreed that career development and retention has a positive significant relation and 7 participants are from 20-30 years old disagree on the statement. In this research employee retention factor contribute to career development. According to this research acquire the talented employees for the organization development and employee career development too. At the other hand retention of employees is important factor retain employees with appropriate benefits for their career development and long stay. According to their analysis employee career development facility has significance in terms of employee retention. 
Hence the study of (Diah, Hasiara, Ramli, \& Irwan, 2019) shows the positive impact of career development on employee retention. In this research study, the respondents were from the pharmaceutical sectors which include 165 males and 151 females which sum up the sample size of 316 . The result comprise, they conducted different tests to check the reliability. The result shows that employee retention has a positive and significant relationship with career development opportunities. The relationship indicates that pharmaceutical companies have their own strategies to maximize the retention rate and maximize their profitability. It's also indicates that investing on development of employees to increase their own profitability and productivity of industry.

Admittedly another study of employee retention of pharmaceutical firms in Indonesia: Taking Investment in Employee development and social and economic exchange as predictor's authors of research are (Diah, Hasiara, Ramli, \& Irwan, 2019). This study object is about the employee career development impact on employee retention. This study stuff motivates to know about the mediating impact of social exchange between perceived investments in employee career development on employee retention. They collected data from the corporate employees of the pharmaceutical firms in which we selected 165 males and 151 females. The total sample population from which the data was selected is 316 . In order to evaluate of this research they applied different tests in the research study. It has been concluded through the results that there is a significant relationship between employee development and Employee retention. Its show a positive results towards the retention on organization.

H4 = Career development opportunities has a positive and significant effect on employee retention.

\section{RESEARCH METHODOLOGY}

\section{Theoretical Framework}


The study is about Employees retention which is indicated by Maslow's hypothesis which involves a 5-level pyramid: physiologic or key perseverance; physical and mental prosperity; sensation of having spot; accomplishment, innovativeness, advancement and selfacknowledgement. Herzberg's hypothesis suggests there are 2 social affairs of components that are tidiness and motivation. The terms job satisfaction and motivation have, in my experience, become used them again. There is a differentiation. Business satisfaction is an individual's eager response to their current work environment condition, while motivation is the primary purpose to pursue and satisfies one's necessities. Maslow and Herzberg's theories can be conveniently applied to the workplace. Heads can help labourers with achieving as a rule position satisfaction which with the employee's internal motivation, increase execution at work.

Similarly, a study by (Alshallah, 2004) asserted that profitability is characterized as the productive and viable utilization of assets with least waste and exertion to accomplish result. We experience a daily reality such that has restricted assets. The pharmaceutical industry faces this impediment more than some other industry. With these difficulties confronting medical services chairmen, the idea of efficiency, work fulfilment and inspiration become significant. Employee fulfilment and retention have consistently been a significant issue for doctors, clinical focuses and organizations all in all. Regular HR speculations, built up about 50 years prior by Maslow and Herzberg, propose that fulfilled representatives will in general be more profitable, inventive and focused on their managers. Individuals are fundamental to profitability. The accomplishment of profitability improvement system is reliant on worker duty, work fulfilment, aptitudes, and inspiration.

\section{Research Approach}

The study is based on mono method research because there is only quantitative research and in this explanatory research is using because we are explaining the phenomena and testing the theory. This is an applied research because the study is applicable to pharmaceutical industries in Pakistan and gives recommendation to the solution of existing problem. 
We collect primary data from the employees of the different pharmaceutical companies of Pakistan. The research approach will be deductive approach as a general theoretical data to a specific data will be collected on pharmaceutical industry of Pakistan. The data collection will be cross sectional.

\section{Procedure}

The study will be accomplished through:

1. Primary data collection done though questionnaire.

2. From Literature review and different research articles we get secondary data.

3. The collected data will be run on SPSS Smart PLS software and Correlational Analysis will be collected and reach to conclusion that which factor affecting most on employee retention in pharmaceutical companies.

\section{Population}

Population of the study is unknown as there are over 400 pharmaceutical firms in Pakistan. We are conducting research on the pharmaceutical firms in Karachi and there are 26 firms of pharmacy are in Karachi in we get responses from 12 companies.

\section{Sample and sampling methods}

The population of the study is unknown so we select our sample size is 250 . We used simple random sampling method for our data collection.

\section{Instrument selection}

The research has selected primary data which will be collected through structured questionnaire which will be measured by 5 point Likert scale. Structured questionnaire will be distributed 
through email among the employees of different pharmaceutical companies of Karachi which will drive us to the conclusion.

6 items of dependent variable employee retention and 6 items of independent variable rewards \& salary are adopted from the study (W. R. \& Wambua, 2019). 4 items of both independent variables i.e. supervisor support and 5 items of career development opportunities are adopted from the study (Wai, 2019).4 items of last Independent variable job satisfaction is adopted from the study (Raziq \& Maula bakhsh, 2015)

\section{Variables}

The variables are taken from the study of (Sinha \& Sinha, 2012) in which they compare the factors influencing on employee retention in two pharmaceutical companies.

Dependent variable: Employee retention

Independent Variables: Supervisor Support, Job satisfaction, Salary \& Rewards, Career Development Opportunities.

\section{Hypothesis}

H1 = Supervisor support have a positive and significant effect on employee retention.

$\mathrm{H} 2$ = Job satisfaction have a positive and significant effect on employee retention.

H3 = Salary \& rewards have a positive and significant effect on employee retention.

H4 = Career development opportunities have a positive and significant effect on employee retention. 


\section{DATA ANALYSIS \& FINDINGS}

The research is about the analyzation of the factors that are affecting on employee retention in pharmaceutical industry of Pakistan. Employees are the assets of any organization. Pharmaceutical industry has load works so it is difficult to retain employees there. It is difficult and costly process to hire a new employee, somehow organization hire the new person but they can't get that experience from new employee so it is necessary for the organizations to work on retaining the employees. This research will explain that which factors effect most on the retention.

The research conducted to identifying the influencing factors that make their influence on employees to retain or leave the organization so that organization may adopt certain strategies to retain their intellectual genius. This is a primary research in which questionnaire (online and physical) is used to collect the data among 250 employees in which 214 employees fill the questionnaire who are working in the pharmaceutical industry of Pakistan like Abbott laboratories, Indus pharma, Adamjee pharmaceuticals, global pharma, Wilshire pharma, Genix pharma, Allmed laboratory, High noon laboratory, Novartis, PharmEvo, Pharmatech and Pharma. The data analysed through SPSS \& Smart PLS-SEM. Different test were conducted to test the reliability and validity of questionnaire.

\section{Descriptive Analysis}

Table 4.1 Respondent profile

\begin{tabular}{|l|l|l|l|l|}
\hline Factors & Respondents & Category & Frequency & Percentage \% \\
\hline Gender & 214 & Male (1) & $1=178$ & Male $=89.0 \%$ \\
\hline
\end{tabular}




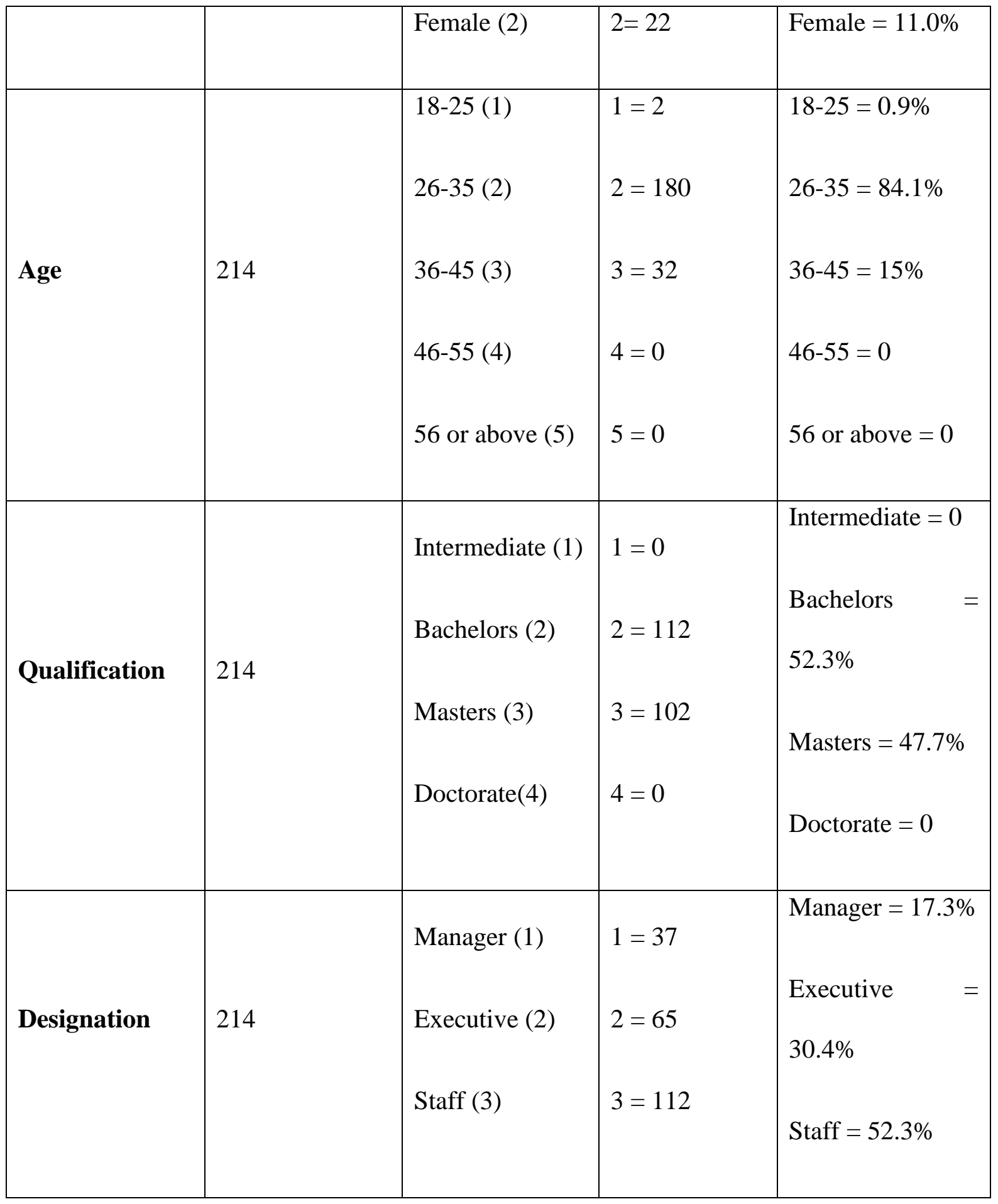

The above table 4.1 shows the figures of demographics related to the employees working in pharmaceutical industry. The research has 214 respondents in which $89 \%$ are male and only $11 \%$ are female. $0.9 \%$ employees belong to $18-25$ age groups, $84.1 \%$ belongs to $26-35 \%$ and only $15 \%$ belongs to $36-45$ age groups. $52.3 \%$ employees are graduated and $47.7 \%$ are masters. 
$17.3 \%$ respondents are managers, $30.4 \%$ respondents are executives and $52.3 \%$ respondents are staff.

Table 4.2 Descriptive analysis table

\begin{tabular}{|c|c|c|c|c|c|}
\hline No. & Variable & Questions & Respondents & Mean & $\begin{array}{l}\text { Standard } \\
\text { Deviation }\end{array}$ \\
\hline 1 & $\begin{array}{l}\text { Employee } \\
\text { retention } \\
(\mathrm{ER} 1)\end{array}$ & $\begin{array}{l}\text { The rate of retention in my } \\
\text { organization is high. }\end{array}$ & 214 & 3.678 & .9463 \\
\hline 2 & ER2 & $\begin{array}{l}\text { I have no intention of } \\
\text { leaving my organization. }\end{array}$ & 214 & 3.893 & .9847 \\
\hline 3 & ER3 & $\begin{array}{l}\text { Within this organization } \\
\text { my work gives me } \\
\text { satisfaction. }\end{array}$ & 214 & 3.911 & .9625 \\
\hline 4 & ER4 & $\begin{array}{l}\text { I am optimistic about my } \\
\text { own future within this } \\
\text { organization. }\end{array}$ & 214 & 3.631 & .9637 \\
\hline 5 & ER5 & $\begin{array}{l}\text { I love working for this } \\
\text { organization. }\end{array}$ & 214 & 3.729 & .9841 \\
\hline 6 & ER6 & $\begin{array}{l}\text { I think my organization is } \\
\text { one of the organizations } \\
\text { with a good job retention } \\
\text { policy for its employees. }\end{array}$ & 214 & 3.668 & .9677 \\
\hline
\end{tabular}




\begin{tabular}{|c|c|c|c|c|c|}
\hline 7 & $\begin{array}{l}\text { Rewards \& } \\
\text { Salary (RS1) }\end{array}$ & $\begin{array}{l}\text { My organization offers } \\
\text { incentives e.g. bonuses, } \\
\text { special packages to } \\
\text { employees. }\end{array}$ & 214 & 3.738 & .9674 \\
\hline 8 & RS2 & $\begin{array}{l}\text { Job grade or group } \\
\text { progression is based on } \\
\text { merit in my organization. }\end{array}$ & 214 & 3.701 & .9711 \\
\hline 9 & RS3 & $\begin{array}{l}\text { My organization generally } \\
\text { has a higher rate of } \\
\text { compensation compared to } \\
\text { other similar } \\
\text { organizations. }\end{array}$ & 214 & 3.869 & 9890 \\
\hline 10 & RS4 & $\begin{array}{l}\text { I believe that my salary is } \\
\text { fair. }\end{array}$ & 214 & 3.659 & .9692 \\
\hline 11 & RS5 & $\begin{array}{l}\text { My organization gives } \\
\text { recognition for } \\
\text { achievements to the } \\
\text { employees. }\end{array}$ & 214 & 3.738 & 9577. \\
\hline 12 & RS6 & $\begin{array}{l}\text { The organization benefits } \\
\text { packages are attractive to } \\
\text { me. }\end{array}$ & 214 & 3.692 & 9584 \\
\hline
\end{tabular}




\begin{tabular}{|c|c|c|c|c|c|}
\hline 13 & $\begin{array}{l}\text { Job } \\
\text { Satisfaction } \\
\text { (JS1) }\end{array}$ & $\begin{array}{l}\text { I am satisfied with the } \\
\text { sense of achievement I get } \\
\text { from my job. }\end{array}$ & 214 & 3.640 & 1.0007 \\
\hline 14 & JS2 & $\begin{array}{l}\text { I am satisfied with the } \\
\text { work I do. }\end{array}$ & 214 & 3.654 & 1.0355 \\
\hline 15 & JS3 & $\begin{array}{l}\text { I am satisfied with the } \\
\text { training I have received. }\end{array}$ & 214 & 3.808 & 1.0552 \\
\hline 16 & JS4 & I feel my job is secure. & 214 & 3.593 & 1.0955 \\
\hline 17 & $\begin{array}{l}\text { Supervisor } \\
\text { Support } \\
\text { (SS1) }\end{array}$ & $\begin{array}{l}\text { My supervisor/boss treats } \\
\text { all employees equally. }\end{array}$ & 214 & 3.701 & 1.0229 \\
\hline 18 & SS2 & $\begin{array}{l}\text { The working environment } \\
\text { maintained by my } \\
\text { supervisor/boss focuses on } \\
\text { teamwork. }\end{array}$ & 214 & 3.682 & .9504 \\
\hline 19 & SS3 & $\begin{array}{l}\text { The supervisor/boss gives } \\
\text { me 'feedback' about how } \\
\text { well I complete my work. }\end{array}$ & 214 & 3.734 & .9830 \\
\hline 20 & SS4 & $\begin{array}{l}\text { My supervisor recognizes } \\
\text { me for work well done. }\end{array}$ & 214 & 3.921 & 9730 \\
\hline 21 & $\begin{array}{l}\text { Career } \\
\text { development }\end{array}$ & $\begin{array}{l}\text { I have received sufficient } \\
\text { training in this }\end{array}$ & 214 & 3.715 & .9485 \\
\hline
\end{tabular}




\begin{tabular}{|c|c|c|c|c|c|}
\hline & $\begin{array}{l}\text { opportunitie } \\
\text { s (CD1) }\end{array}$ & $\begin{array}{l}\text { organization to enable me } \\
\text { do my job effectively. }\end{array}$ & & & \\
\hline 22 & CD2 & $\begin{array}{l}\text { My organization provides } \\
\text { regular training. }\end{array}$ & 214 & 3.869 & 9937. \\
\hline 23 & CD3 & $\begin{array}{l}\text { The training that has been } \\
\text { provided enables my } \\
\text { personal growth. }\end{array}$ & 214 & 3.706 & 9356 \\
\hline 24 & CD4 & $\begin{array}{l}\text { There are opportunities in } \\
\text { this organization for me to } \\
\text { advance my career. }\end{array}$ & 214 & 3.757 & .9429 \\
\hline 25 & CD5 & $\begin{array}{l}\text { The organization has } \\
\text { career development } \\
\text { activities to help an } \\
\text { employee identify/ } \\
\text { improve abilities, goals, } \\
\text { strengths, and weaknesses. }\end{array}$ & 214 & 3.991 & 9494 \\
\hline
\end{tabular}

The above table 4.4 shows the figures of descriptive analysis which is related to the working employees of pharmaceutical industry. The research has 214 respondents and we have a variable according our research topic which is employee retention, rewards and salary, job satisfaction, supervisor support and career and development opportunities.

- Our ER1 indicates the result by $1^{\text {st }}$ question of respondents means is 3.678 and Standard deviation is .9463 and ER2 Means is 3.893 and SD is .9847 and ER3 Means is 3.911 and 
SD is .9625 ER4 Mean is 3.631 and SD is .9637 ER5 Mean is 3.729 and SD is .9841 ER6

Mean is 3.668 and SD is .9677.

- Salary and rewards shows the analysis of RS1 mean is 3.738 and SD is .9674 RS2 mean is 3.701 and $\mathrm{SD}$ is $.9711 \mathrm{RS} 3$ mean is $3.869 \mathrm{SD}$ is $.9890 \mathrm{RS} 4$ mean is $3.659 \mathrm{SD}$ is $.9692 \mathrm{RS} 5$ mean is $3.738 \mathrm{SD}$ is $.9577 \mathrm{RS} 6$ Mean is 3.692 and SD is .9584.

- Job Satisfaction analysis table show the result of JS1 mean is 3.640 and SD is 1.0007 JS2 mean $3.654 \mathrm{SD}$ is $1.0355 \mathrm{JS} 3$ mean is $3.808 \mathrm{SD}$ is $1.0552 \mathrm{JS} 4$ mean is 3.593 and SD is 1.0955

- Supervisor support show the results of SS1 mean is 3.701 and SD is 1.0229 and SS2 mean is 3.682 and SD is $.9504 \mathrm{SS} 3$ mean is $3.734 \mathrm{SD}$ is $.9830 \mathrm{SS} 4$ mean is 3.921 and SD is .9730 .

- Career and Development opportunities demonstrate the descriptive analysis results of CD1 mean is 3.715 and SD shows .9485 CD2 mean is 3.869 and SD is .9937 CD3 Mean 3.706 and SD is .9356 CD4 show the mean is 3.757 and SD is comes .9429 and CD5 of mean is 3.991 and the SD is .9494 .

\section{CONCLUSION}

Employees retention based on the salary and rewards. All factors are depending on salary. Salary and rewards increase the job satisfaction and employees retention. This study examines the factors which is effecting employees retention and staying long for pharmaceutical industry. The result suggests that the factors which had satisfyingly explained Salary \& Rewards and job satisfaction which is affect the employees' retention. The outcomes recommend that the variables had acceptably clarified Job satisfaction and Compensation and other variable supervisor support and career opportunity also play significant role on the factors that has an effect on supervisor support and job satisfaction. In light of the outcomes for the normalized values, we can see that work conditions, reasonableness, advancement, and pay, are key 
variables that influence pharmaceutical industry workers' job fulfilment. Money is a biggest role playing, in reality that everyone's worked for money they just want money, need money and worked for money. What's more, acceptable pay is key variables in satisfying the employee. We can enhance the incentives and remuneration of the employees to rouse the representative, the great compensation back can be one of the key components influencing position fulfilment, additionally in this way one can expand the administration quality and hierarchical execution. These all things relate to the employees retention and a good work environment and good work condition can increase the job satisfaction of employees and increase their job performance too. For the satisfaction of employees provide them good services and attractive packages for their benefits.

\section{Recommendations}

Future chances about the research study is that overcoming the limitations of data collection and future study need to observe more about the pharmaceutical working environment and their working conditions because they only worked for money and there is less career opportunities so we future worked on it and find the reasons. Future more research on promotions, job security and relationship with their co-workers. For further research following examine should be considered.

1) The research needed to future working on the other factors which is more needed and know about the factors which influenced the employees retention of pharmaceutical industry. Variable like: Such as role ambiguity, job uncertainty, work level, contingent rewards and prizes and collaborate have on employees retention and satisfaction.

2) Create a good and pleasant environment for employees according to their work condition and comforts. Interaction with your employees and communicate with them 
to build a good relationship as a supportive supervisor or co-worker because it creates a good work environment.

3) Evaluate their performance and work quality and appraisal them accordingly to their good performance and utilize their more skills by appraisal because its motivation factors for every employees to retain, satisfy and beneficial for industry.

4) Rewards should be based on truly merit system.

5) Turnover rate should be monitor and know about the reasons of turnover and make a policy regarding this factor because it's helpful for organization to retaining employees.

6) Offering them advancement training for career opportunity which is helping them to increase their skills.

\section{Further area for Research}

It will never be ignored that beside conduct a fruitful research but there are some limitation needs to be discussed compulsory that can help for the further research. Data was collected among 214 employees of various pharmaceutical companies of Karachi, Pakistan within the limited time, if data was collected from all over the country of Pakistan or from maximum cities of it without any restriction of time, the research would generate more productive results. May be some of the respondents may attempt questionnaire inattentively, on the other hand the questionnaire was prevailed among the certain age groups but majority of the respondents were between the $26-35$ age group and only $15 \%$ belongs to $36-45 \%$ while there are only $11 \%$ of respondents are females. These things could bring an effective result in research.

We work on dependent variable is (Employee retention) and independent variables (Supervisor support, job satisfaction, salary \& rewards and career development opportunities) \& I observe during the entire research from survey, questionnaire \& past literature that all factors directly and indirectly impacts on employee retention. 


\section{REFERENCES}

Hejase , H. J., Dirani, A., Hamdar, B., \& Hazimeh, B. (2016). Employee retention in the pharmaceutical companies: Case of Lebanon. 58-75.

Kossiv, B., Xu, M., \& Kalgora, B. (2016). Study on determining factors of employee retention. 262-268.

Afshan, G., Qamar, F., \& Afzal, K. (2018). Factors Influencing Employee Retention in Public Organization: A Quantitative Study in hospitals of Quetta. 30-51.

Akhter, S., \& Iqbal, S. (2017). Effects of job organizational culture, benefits, salary on job satisfaction ultimately affecting employee retention. 7 .

al, H. e. (2015).

Ali Kara, F. D. (2013, July 3). Supermarket self-checkout service quality, customer satisfaction, and loyalty: Empirical evidence from an emerging market. Journal of Retailing and Consumer Services.

Allvine, F. C. (1968, October). The Supermarket Challenged new competitive strategies needed.

Alshallah, S. (2004). Impact of employee retention in pharmaceutical industry. 47-51.

Anis, A. (2011). Impact of organizational commitment on job satisfaction and employee retention in pharmaceutical industry.

Anis, A., Kashif-ur-Rehman, Ijaz-Ur-Rehman, Khan, M., \& Humayoun, A. A. (2011). Impact of organizational commitment on job Satisfaction Satisfaction and employee retention in pharmaceutical industry. 7316-7324. 
Ashika, M. J. (2020). Examining the Factors Contributing to Employee Retention of BEXIMCO-The case study on HR Department of BEXIMCO Pharma. 20.

Ashtraf, T., \& Siddiqui, D. A. (2018). The impact of employee engagement on employee retention: the role of psychological, capital, control at work, general wellbeing, and job satisfaction. 67-93.

Baig, S. A., Saqib, S., Abrar, M., \& Bashir, M. (2011). Relationship between Rewards and Employee Motivation in the pharmaceutical industry of Pakistan. 327-334.

Bauerová, R. (2018, January). Consumers' Decision-Making in Online Grocery Shopping: The Impact of Services Offered and Delivery Conditions. Acta Universitatis Agriculturae et Silviculturae Mendelianae Brunensis, 66(5).

Bibi, P., ahmed, A., \& Majid, A. (2018). The impact of training and development and supervisors support on employees retention in academic institutions in Pakistan. 113131.

Chew, J., \& C. A. Chan, C. (2008). Human resource practices, organizational commitment and intention to stay. 503-522.

Chiu, R. K., \& Li-Ping Tang, T. (2002). Retaining and motivating employees: Compensation. $402-431$.

Dauerova, R. (2018). Consumers Decision making an Online Groscery Shopping, The Impact of services offered and Delivery conditions. Acta universitatis Agriculturae ET Silbiculturae mendelianae brunensis, 66. Retrieved from htttps://doi.org/10.11118/actaun201866051239

Dhurup, P. F. (2005). Consumer perception of supermarket service quality: Scale development and validation. Dept of business managemnet, North Waste University(4). 
Diah, A. M. (2019). Employee Retention of Pharmaceutical Firms in Indonesia: Taking Investment in Employee Development and Social and Economic Exchange as Predictors. 564-572.

Diah, A. M., Hasiara, L., Ramli, \& Irwan, M. (2019). The study of Employee Retention of Pharmaceutical Firms in Indonesia:Taking Investment in Employee Development and Social and Economic Exchange as Predictors. 564-572.

Garland, A. T. (1993). SUPERMARKET SHOPPING LISTS: THEIR EFFECT ON CONSUMER EXPENDITURE. International Journal of Retail \& Distribution Management.

George, C. (2015). Retaining professional workers: what makes them stay? Employee Relations. 102-21.

Imam, T., \& Ali, H. (2018). Dilemma of Employee Retention through the Lens of Organizational Politics: A Quantitative Study on Pharmaceutical Industry of Pakistan. 26-36.

Irshad, M., \& Afridi, F. (2007). Factors affecting employees retention: Evidence from literature. 307-339.

J. Beneke, C. H. (2012). Examining the effect of retail service dimentions on customer satisfaction and loyalty ( The case of the super market shop). Acta Commercii.

Kabir, M. M., \& Parvin, M. M. (2011). Factors affecting employee job satisfaction of pharmaceutical sector. 113-123.

khan, A. h., \& Aleem, M. (2014). Impact of job satisfaction on employee turnover: An empirical study of autonomous medical institutions of Pakistan. 122-132.

Kroeger, J. (2010). Organizational Benefits of Retaining Older Workers. 80.

Malik, E., Baig, S., \& Manzoor, U. (2020). Effect of HRM practices on employee retention:The role of perceived supervisor support. 1-7. 
Mishra, D. S., \& Mishra, D. (2013). Review of literature on factors influencing attrition and retention. 435-444.

Nagarathanam, R., Venkitasamy, S., \& Attiah, E. M. (2018). The impact of career development practices on employees' retention. 225-330.

Nguyen thuha, N. H. (2015). The relationsip between service quality and customer loyalty in sepcially supermarket: Emprical evidance in vietnam. Internal journal of business and economic research , 1, 4.

Pane, R. N. (2015, January 1). The effect of brand image on customer satisfaction and loyalty intension in retail supermarket chain UK. International Journal of social sciences and management, 3 .

Raziq, A., \& Maula bakhsh, R. (2015). Impact of Working Environment on Job Satisfaction. $717-725$.

Ruvimbo, S., \& Ngirande, H. (2014). The impact of reward on job satisfaction and employee retention. 481-487.

Salman, S., Mehmood, A., Aftab, F., \& Mahmood, A. (2016). Impact of safety health environment on employee retention: Retention in pharmaceutical industry. 185-197.

Schechter, Shaked, \& H. (2018). Systems Thinking for School Leaders: Holistic Leadership for Excellence in Education. Cham, Switzerland. 647-649.

Singh, H. (2018). Determinants of employee retention in an organization: An Empirical Investigation. 140 - 143.

Sinha, C., \& Sinha, R. (2012). Factors Affecting Employee Retention: A ComparativeAnalysis of two Organizations.

Sinha, D., \& Shukla, D. K. (2013). A study of employee retention in pharmaceuticals sector in Dehradun city. 30-39. 
Siu, N. Y. (2003, January). Service Quality in Grocery Retailing. Journal of International Consumer Marketing.

Sucharski, I. L., Stinglhamber, F., \& Vandenberghe, C. (2002). Perceived superior support: Contribution to perceived organizational support and employee retention. 565-573.

W. R., N., \& Wambua, P. (2019). Strategic human resource management practices and employee retention in Commercial Banks in Nairobi City County, Kenya. Journal of Human Resource and Leadership,. 73-89.

Wai, K. H. (2019). Yangon university of economics department of commerce. 